\title{
Designing and implementing a STEM career maturity program for prospective counselors
}

\author{
Engin Karahan ${ }^{1 *}$ D, Ahmet Kara² and Ahmet Oğuz Akçay ${ }^{3}$
}

\begin{abstract}
Background: Although the importance of directing students to career options in Science, Technology, Engineering, and Mathematics (STEM) fields at early ages has been emphasized in the literature, it has not been clearly stated just who will play a role in this process and what kind of consultancy process will be followed. It is of great importance for prospective counselors, who are studying in the field of counseling, to master the career selection process, specifically for STEM, towards achieving the national goals. Therefore, the purpose of this study was to investigate the career counseling competencies of prospective counselors who were participating in a STEM career maturity program.

Findings: The current study employed the mixed-methods sequential explanatory design. In this design, after collecting and analyzing the quantitative and qualitative data, both datasets were then interpreted together. The quantitative data analysis revealed a significant difference between the post-test mean career counseling and performance indicator scores of the experimental and the control groups $(u=49.00 ; P<0.05)$. The career counseling and performance indicator mean rank and sum of mean scores of the students in the experimental group were higher than those of the students in the control group. The mean career counseling and performance indicator scores of the students in the experimental group increased after the experimental application $(Z=-3.07$; $P<0.01$ ). Moreover, the effect size was also calculated and determined to be 0.58 . As a result of the analysis of qualitative data, 4 themes were established, comprising (1) personal and professional development, (2) awareness of the STEM majors and careers, (3) STEM-focused career counseling, and (4) feedback about the program.

Conclusions: This study found that the STEM career maturity program that was designed and implemented herein resulted in positive impacts on the career counseling competencies and performance indicators of the participants, as well as their knowledge and awareness of professional STEM areas. Considering the role of school counselors in supporting students in choosing STEM careers, this newly proposed STEM career maturity program will provide a strong model for supporting pre-service and in-service school counselors in directing students towards STEM fields, so as to develop a qualified workforce in STEM fields, which is one of the main objectives of the STEM education reform.
\end{abstract}

Keywords: STEM education, Career counseling, Career maturity, Mixed methods

\footnotetext{
* Correspondence: ekarahan@ogu.edu.tr

${ }^{1}$ Department of Curriculum and Instruction, Eskisehir Osmangazi University,

Eskisehir, Turkey

Full list of author information is available at the end of the article
}

\section{Springer Open}

(c) The Author(s). 2021 Open Access This article is licensed under a Creative Commons Attribution 4.0 International License, which permits use, sharing, adaptation, distribution and reproduction in any medium or format, as long as you give appropriate credit to the original author(s) and the source, provide a link to the Creative Commons licence, and indicate if changes were made. The images or other third party material in this article are included in the article's Creative Commons licence, unless indicated otherwise in a credit line to the material. If material is not included in the article's Creative Commons licence and your intended use is not permitted by statutory regulation or exceeds the permitted use, you will need to obtain permission directly from the copyright holder. To view a copy of this licence, visit http://creativecommons.org/licenses/by/4.0/. 


\section{Introduction}

Adolescence is a stage in the life of an individual when they begin a search for identity, which is also one of the career development stages (Super, 1980). Adolescents going through this search for identity are within the process of realizing their interests, abilities, and values and they start to develop a perspective in relation to them. They then use these perspectives that they have developed to compare various professions. In addition, in terms of career development, adolescents begin to understand that professions are a part of life. They form opinions about professions and make decisions and choices based on the options presented to them. As a result, the most important career development task expected from adolescents in this period is the choice of a career.

The ultimate goal of choosing a career is for an individual to create a future in which they can be happy (Super, 1980). While creating this future, it is extremely important for adolescents to carefully analyze their own personal traits, interests, abilities, values, professional orientation, and career choices. To do so, adolescents should be oriented towards choosing a profession, collecting information, and making plans about the preferred profession, determining the consistency of the professional preferences, crystallizing their professional identities, and attaining professional independence. At this point, the concept of career maturity is important in the acquisition of the above-mentioned features. Career maturity refers to the psychological, social, and biological readiness of the adolescent to choose a profession (Super \& Knasel, 1981). Therefore, it is the most important determinant of choosing a career. Individuals need to reach a certain level of maturity when choosing a profession during adolescence (Super, 1980). Both theoretical and empirical studies have revealed that individuals with a high level of career maturity are ready for the choice of a profession, while those with a low level of career maturity may postpone making professional decisions or feel unsuccessful and inadequate (Crites, 1969; Super, 1980; Super \& Knasel, 1981; Yesilyaprak, 2011).

One of the main objectives of a recent global educational reform called Science, Technology, Engineering, and Mathematics (STEM) education has been to develop a qualified workforce in STEM fields and increase the number of people that have careers in these fields. In order to achieve this goal, STEM education has focused on increasing the number of individuals who develop their STEM skills through experiences such as career and technical education at the K-12 level, gain the necessary competencies for STEM professions, and continue their professional degrees in one of the STEM fields (National Research Council, 2011). Therefore, it is of great importance to direct students towards STEM fields in order to increase the number of professionals in STEM professions and careers around the world. On the other hand, a shortage of qualified STEM professionals continues to threaten countries in global competitiveness (Noonan, 2017). In this regard, most countries define STEM education as one of the priority areas at the national level (Rinn \& Kettler, 2020). To illustrate, STEM working groups have been established to conduct studies that emphasize the importance of STEM education, and the need for a STEM workforce in order to increase the innovation capacity, competitiveness, and welfare level of the countries (Turkish Industry and Business Association (TUSIAD), 2017).

The starting point of counseling services is the field of vocational guidance and career counseling. In 1909, the first career guidance studies were initiated by Parsons and the cornerstones of counseling services were established. The lifestyles, life roles, self-structures, and interpersonal relationships of individuals are shaped by their professions (Yesilyaprak, 2011). The profession that an individual has is an important factor that forms and defines his or her identity (Herr et al., 2004). Therefore, the most crucial role and function of psychological counselors at any level of education is to help students prepare for their profession and career, create options, and make decisions. In addition, the modern education system aims to train individuals who are productive, happy, and able to develop and demonstrate their potential at the highest level (Herr et al., 2004). As a result, the field of vocational guidance and career counseling is of vital importance in imparting the above-mentioned characteristics. At this point, it is extremely important for prospective counselors to be trained in such a way as to equip them with knowledge and skills about the career development tasks involved in the process of preparing students for career preparation, career orientation, career choice, career maturity, and career development.

\section{Literature review}

In modern society, a profession is the sum of activities that helps individuals to gain a place, status, and economic independence, self-actualize, and add meaning to their lives (Yesilyaprak, 2011). Clarifying their life roles and getting to know themselves and the meanings that they attach to their lives are all related to their professions. Professional orientation is a concept that refers to the extent to which an individual wants to work in or intends to enter a profession. Professional preference is defined as the process of an individual putting jobs in order in terms of their desirability or accessibility (Kuzgun, 2003). Moreover, the career development task that is expected from adolescents after career orientation and preference is to choose a profession. The main goal of 
choosing a career is to create a career future where the individual will feel happy, peaceful, and productive (Super, 1980). Ayas et al. (2010) put forward the factors affecting career choice, stating as individual values, emotional factors, type and duration of education, and environmental pressures. On the other hand, in career counseling, it has been stated that the most important variable affecting career choice is career maturity (Super, 1980).

The concept of career maturity emerged from the lifespan, life-space theory that was put forth by Super (1980), who defined career maturity as the level of successfully performing career development tasks during the career development stage, in which a person is in parallel with his/her social, biological, and psychological development. According to Crites (1969), career maturity is defined as a career variable that has an affective dimension that is related to attitudes towards the career development process, as well as a cognitive dimension including the knowledge that the individual has of the profession and decision-making skills. Savickas (1984) defined career maturity as the capacity to have the competencies to perform career development tasks during the career development stage of the individual. Yesilyaprak (2011), on the other hand, described career maturity as a psycho-social structure, which includes attitudinal elements such as career maturity, career planning in career development, career curiosity, career discovery, as well as cognitive elements, such as career decision-making and obtaining information about the profession, which reflect the readiness level of the individual to make a healthy career choice according to these attitudinal and cognitive competences.

\section{STEM education}

The concept of STEM education first emerged in the 1990s (Kelley \& Knowles, 2016). It was created by combining the initials of the Science, Technology, Engineering, and Mathematics disciplines, and aims to teach these four disciplines in an integrated manner in the context of real-life problems (Bybee, 2013). The most recent education reform based on the integration of different disciplines is the STEM education approach, which is based on the adoption of a holistic approach to STEM. The basis of this approach is to teach the knowledge and skills of these disciplines in a real-world context with an interdisciplinary and holistic approach, rather than teaching the four disciplines independently of each other (Karahan, 2020). Another dimension of STEM education is to raise the standards of science and mathematics education at the $\mathrm{K}-12$ level and provide students with higher competence and motivation towards STEM (National Academy of Engineering, 2009; National Academy of Sciences, 2006).
One of the main objectives of STEM education is to train STEM literate individuals with twenty-first century skills and include these individuals in the STEM workforce (Honey et al., 2014). As defined by the World Economic Forum, twenty-first century skills have 16 dimensions, including skills such as scientific and financial literacy, creativity, communication, critical thinking, problem solving, and entrepreneurship (World Economic Forum, 2015). Bybee (2013) is another researcher who put forward STEM literacy as the primary goal of STEM education. He addressed the characteristics of STEM literate individuals as being able to identify life problems; explain natural and designed environments; having the knowledge, attitudes, and skills necessary to produce evidence-based solutions to STEM-related problems; understanding the characteristic features of STEM disciplines, such as knowledge, discovery, and design; being aware of how STEM disciplines affect intellectual and cultural environments; and being interested in STEM-related subjects.

\section{STEM career}

In Turkey, reports have indicated that the choice towards STEM fields of top-ranked students based on their university entrance exam scores has decreased over time (Akgunduz, 2016). In a report published in the ASPIRES: Young People's Science and Career Aspirations Project in 2013, it was stated that many students between the ages of 10 and 14 years were not inclined to choose a career in science. In addition, it was stated that most 10-14-year-old students, and even their parents, had a narrow view of where science can go (Archer et al., 2014). A report issued by TUSIAD (2017), entitled the "Need for STEM in Turkey towards 2023," argued that a significant number of graduates of STEMcentered fields were employed in fields outside of STEM. In the same report, the most important reason for this was said to be the insufficient awareness that the students had of STEM fields and their lack of knowledge about the relationship between these fields and their abilities. Moore and Richards (2012) pointed to the importance of early intervention in the STEM-focused career choices of students and emphasized that the awareness that students had of their STEM-focused career choices should be increased.

With early intervention in the education system, awareness of choosing a STEM-focused career can be increased for students by enabling them to choose a career consciously (Moore and Richards, 2012). Given that professional tendencies emerge at early ages, it is necessary to determine the interest of the students in STEM careers at early ages. Middle school years play an important role in career planning (Hirsch et al., 2007). Furthermore, Kier et al. (2014) emphasized that interest 
in STEM fields should begin in middle school years for STEM-focused career choice. However, a study by Spencer (2011) emphasized that many 7th-grade students do not know which courses were sufficient or appropriate for engineering. Increasing the awareness of students about the transferability of their science competencies to these professions in the choice of profession, by emphasizing the importance of science, makes students more conscious of their career choice (Archer et al., 2014). In addition, it was emphasized that when the perceptions of the teachers towards STEM education are high, then the perspectives of the students about STEM education and STEM-oriented career choices are also high.

There are studies in the literature that have shown that teachers have one of the most critical roles in directing the interest of students in STEM disciplines and career fields (Ejiwale, 2013; Epstein \& Miller, 2011). Although the importance of directing students to career options in STEM fields at early ages has been emphasized in the national and international literature, it has not clearly been stated just who will play a role in this process and what kind of consultancy process they will follow. This is one of the primary responsibilities of psychological counselors, vocational guidance, and career counseling services; however, it has not been possible for them to have the opportunity to gain awareness on this issue in either the pre-service or in-service training processes. Therefore, it is of great importance for prospective counselors, who are studying in the field of counseling, to master the career selection process specifically for STEM, towards achieving the national goals. The purpose of the current study was to investigate the career counseling competencies of prospective counselors who were participating in a STEM career maturity program. From this perspective, answers to the following research questions were sought.

1. How do the career counseling competencies of the prospective counselors participating in a STEM career maturity program change?

a. Is there a significant difference between the career counseling competencies and the performance indicator scale pretest mean scores of the experimental and control groups?

b. Is there a significant difference between the career counseling competences and the performance indicator scale posttest mean scores of the experimental and control groups?

c. Is there a significant difference between the career counseling competences and the performance indicator scale pretest and posttest mean scores of the experimental group?

d. Is there a significant difference between the career counseling competences and the performance indicator scale pretest and posttest mean scores of the control group?

e. How do the prospective counselors evaluate the effectiveness of the STEM career maturity program?

\section{Theoretical framework}

The structure of career maturity has been studied since Super defined this concept in 1955. Career maturity is a multidimensional psycho-social structure that includes both the cognitive and affective dimensions of career development tasks in the career development periods of an individual (Super, 1980). It has been described as the degree of professional development that an individual has demonstrated from the period of imaginary choices in early childhood until retirement (Crites, 1969), and the ability of an individual to overcome the professional development tasks of the developmental period (Savickas, 1984). A career maturity model for adolescents was developed by Super (1980). In this model, adolescents are at the searching stage of career development. The most important career development task that adolescents at this stage are expected to do is choose a career. On the other hand, there are many factors affecting career choices. The most important of these factors is career maturity, because it shows the level of preparedness towards a career choice. Individuals with a high level of career maturity are ready for the choice of a profession, while individuals with a low level of career maturity may postpone making professional decisions or feel unsuccessful and inadequate (Super \& Nevill, 1984).

Super's theory of career maturity can be defined as the readiness of an individual to deal with the developmental tasks appropriate for their career stage (Kidd, 2006). A longitudinal career pattern research (Super and Overstreet, 1960) led Super (1974) to identify six dimensions of career maturity in adolescents. In addition to Super's (1974) career maturity dimensions, other researchers have provided various predictors to expand on his theory since its initial inception. For instance, Crites (1971) argued that making career decisions, choosing a job, and using problem solving skills are part of career maturity. In their longitudinal study, Creed and Patton (2003) found that age, career decision, and work commitment are also important predictors of career maturity. Finally, adaptation in interpersonal relationships and positive orientation to social norms were found to be important factors in career maturity (Savickas et al., 2002). The career maturity model developed by Super (1974) for adolescents is shown in Fig. 1 below. 


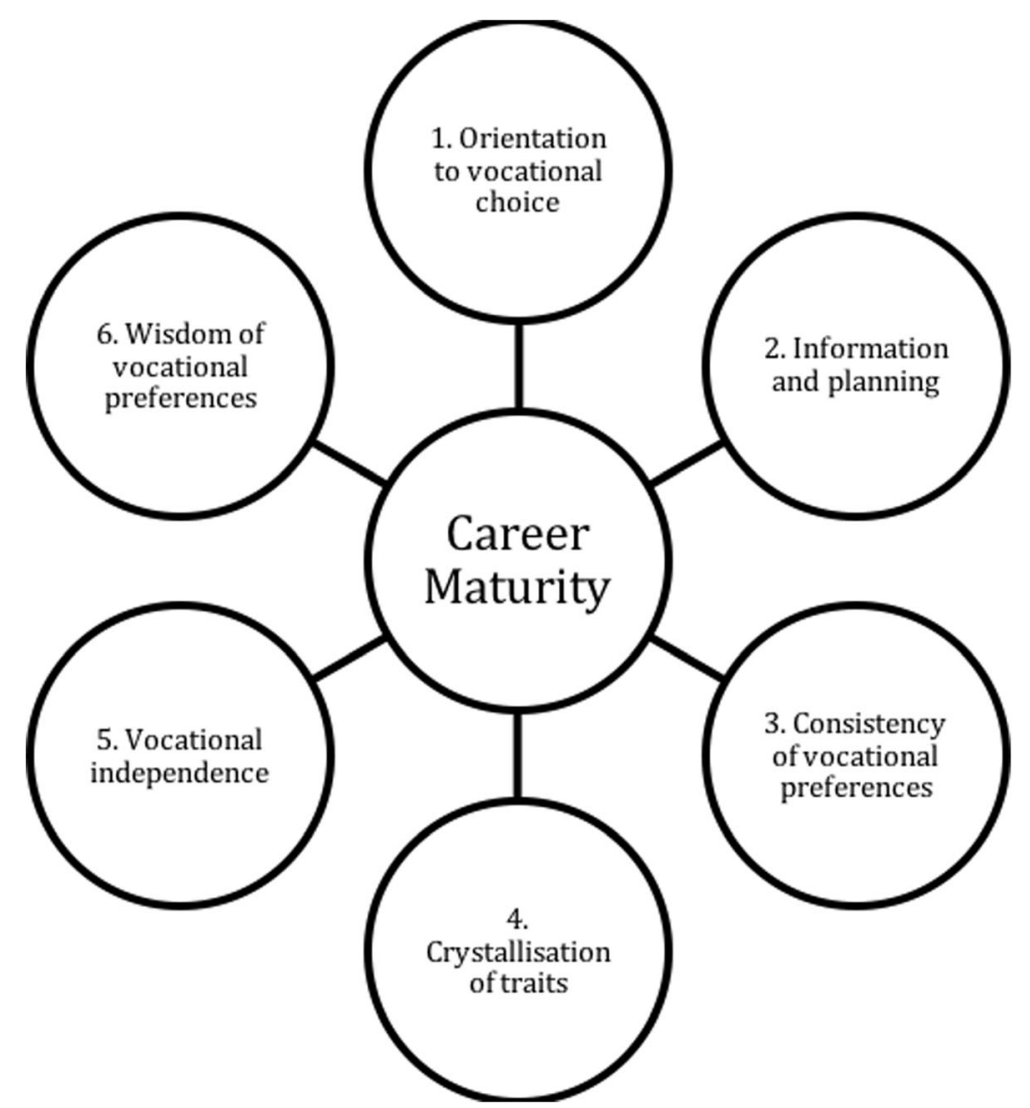

Fig. 1 Dimensions of career maturity (Super, 1974)

Theory related to career maturity Super's life-span, life-space theory

Super's life-span, life-space theory is known as the most important developmental theory in career counseling. Super introduced many concepts to the field of career counseling. These concepts include career maturity, development of self-concept, life spaces and life-span, stages of career development, and career development tasks. These concepts are explained below.

\section{Self-concept}

Self-concept emerges as an important concept in Super's life-span, life-space theory. According to Super (1980), the development of the self-concept and career development process are similar. On the other hand, career choice is the expression of self-concept with the name of the profession. In other words, career choice is defined as applying one's self in the field of the profession. According to Super (1980), there are two types of self in career counseling, which comprise professional identity and professional self-concept. Professional identity is the universal characteristics that are verified by the measuring the tools that the person has objectively. Professional self-concept is the subjective judgments that a person develops against himself/herself (Super, 1980).

\section{Life-spaces and life-span}

Super (1980) stated that while structuring their career development process, individuals are involved in nine life roles and four life spaces. These life roles include the child, student, leisure, citizen, worker, spouse, homemaker, parent, and pensioner, while the living spaces include the home, community, school, and workplace (Super, 1980). The life space, on the other hand, gives information about the life roles, lifestyles, values, and interests of the individual. Life-span provides information about career development periods and career development tasks of the individual. As a result, life-span corresponds to the process dimension of career development and life-space corresponds to the content dimension (Super, 1980).

\section{Super's career development stages and career development tasks}

Super's life-span, life-space theory describes the five career development periods and the career development tasks that an individual is expected to do for each 
period. Super's career development periods and career development tasks (Super, 1980) are given in Table 1.

\section{Method}

\section{Research model}

The current study employed the mixed-methods sequential explanatory design (see Fig. 2). In the mixedmethods sequential explanatory design, first, the quantitative data were collected. Next, the qualitative data were collected to reach more detailed explanations and then analyzed. Finally, both the quantitative and qualitative datasets were interpreted together (Creswell, 2013).

The quantitative dimension of the current study was conducted using the quasi-experimental pretest-posttest design with an experimental and a control group. In the qualitative dimension of the study, the phenomenological design was used. The phenomenological design allowed an in-depth exploration of the meanings and experiences that the participants had about the phenomenon (Patton, 2014), as well as how the participants made sense of the concept of STEM career maturity and what experiences they had about the concept. Finally, the quantitative data collected with the quasiexperimental design and the qualitative data collected with the phenomenological design were interpreted together.

\section{Study group}

The study group consisted of fourth-year undergraduate students who were selected via the purposive sampling method from students attending the Department of
Counselling at the Faculty of Education of a public university in the 2019-2020 academic year. There were a total of 160 fourth-year students attending this department. The students were administered the Career Counselling Competencies and Performance Indicators (CCCPI) scale, which was developed by the USA National Career Development Association (NCDA) in 1997, and the purpose, procedure, and duration of the study were explained to them. When the scores taken from the scale were ordered, a total of 28 students whose scores remained one standard deviation below the arithmetic mean were included in the current study. The reason for taking one standard deviation below the arithmetic mean was to include those who scored lower than the CCCPI scale in the study group. Through group matching of the participants, 14 students were assigned to the experimental and control groups. Brown (2004) stated that the number of participants in psychoeducational groups is a key consideration, since it plays a significant role in deciding how much attention can be devoted to each individual. Therefore, it was decided that the number of participants in each group would be 14. The criteria of inclusion in the current study, within the context of the purposive sampling, comprised:

1. Being a fourth-year student attending the Department of Counselling in the Faculty of Education at a public university in the 2019-2020 academic year,

2. Attaining a score from the scale that was one standard deviation below the arithmetic mean, and

Table 1 Career development periods and career development tasks (Super, 1980)

\begin{tabular}{|c|c|c|c|c|}
\hline $\begin{array}{l}\text { Career development } \\
\text { periods }\end{array}$ & Age group & $\begin{array}{l}\text { Development } \\
\text { period }\end{array}$ & Career tasks & Developmental characteristics \\
\hline Growth & $\begin{array}{l}0-14 \text { years } \\
\text { old }\end{array}$ & Childhood & - & $\begin{array}{l}\text { Children try out professional roles through fantasy and games. } \\
\text { They identify with the professional roles of their parents. They } \\
\text { are not realistic when they say that they will choose this profession. }\end{array}$ \\
\hline Exploration & $\begin{array}{l}15-24 \text { years } \\
\text { old }\end{array}$ & Adolescence & $\begin{array}{l}\text { Clarification } \\
\text { Determination } \\
\text { Application }\end{array}$ & $\begin{array}{l}\text { During this period, adolescents begin to become aware of their } \\
\text { professional interests, needs, values, abilities, and personality traits. } \\
\text { They become more conscious of themselves and try adult roles } \\
\text { consciously. They have clear ideas about the profession. This covers } \\
\text { the period when individuals decide to choose a profession and enter } \\
\text { into business life. Therefore, career maturity is in the center of this } \\
\text { period. }\end{array}$ \\
\hline Establishment & $\begin{array}{l}25-44 \text { years } \\
\text { old }\end{array}$ & $\begin{array}{l}\text { Emerging a } \\
\text { dulthood/ } \\
\text { adulthood }\end{array}$ & $\begin{array}{l}\text { Deciding } \\
\text { Reinforcing } \\
\text { Progressing }\end{array}$ & $\begin{array}{l}\text { This is the period when the individual starts his/her working life and } \\
\text { begins to apply the self-concept in the profession. }\end{array}$ \\
\hline Maintenance & $\begin{array}{l}45-65 \text { years } \\
\text { old }\end{array}$ & Adulthood & $\begin{array}{l}\text { Protecting } \\
\text { Updating } \\
\text { Innovation }\end{array}$ & $\begin{array}{l}\text { This is the period when individuals are productive and maintain their } \\
\text { positions at work. After gaining a certain status in business life, all } \\
\text { efforts are directed towards retaining and renewing it. There can be } \\
\text { ups and downs, and pauses in their business lives. }\end{array}$ \\
\hline Decline (pensioner) & $65+$ years old & Old age & $\begin{array}{l}\text { Slowing } \\
\text { Retirement } \\
\text { plan } \\
\text { Retirement }\end{array}$ & $\begin{array}{l}\text { This is the period when the physical and mental abilities of the elderly } \\
\text { decrease, their interest and energy towards the profession decreases, } \\
\text { and retirement plans are made. In this period, individuals act by using } \\
\text { their past experiences and knowledge rather than their physical strength. }\end{array}$ \\
\hline
\end{tabular}




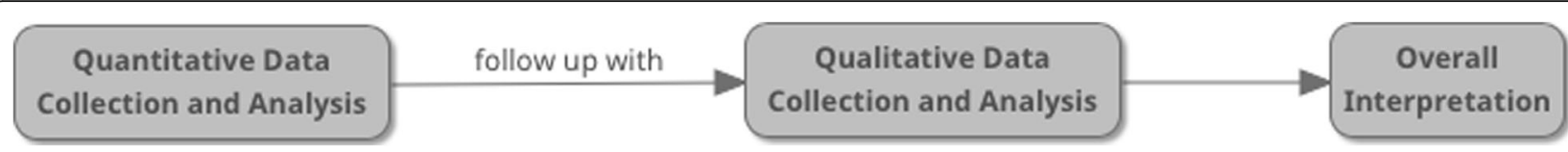

Fig. 2 Mixed-methods sequential explanatory model adapted from Creswell (2013)

3. Volunteering to participate in the study.

\section{STEM career maturity program}

While preparing the STEM career maturity program, the theoretical views on career maturity and experimental studies designed for similar purposes in the literature were reviewed first (Ayas et al., 2010; Esters \& Retallick, 2013; Karatas \& Yavuzer, 2009; Shdaifat, 2019). Next, in line with the purpose of the current study, the psychoeducation group method was used, which is a group type that has educational content, aims to develop skills, and includes the objectives to be achieved (Brown, 2004). In these groups, effort was made to increase the knowledge of the participants, raise their awareness of themselves, and teach certain skills. Group-based training and development strategies, such as role-playing, problem solving, decision-making, and communication skills, are preferred in psycho-education groups (Brown, 2004). Super's career maturity model was selected as the theoretical basis of the STEM career maturity program. The reason for choosing this theory as the basis was that the six-dimensional career maturity model for middle school students was first and comprehensively developed by Super (1974); hence, the career maturity program was prepared by considering those same six dimensions. The content of the STEM career maturity program is presented in Table 2.
The current study was conducted in six sessions. In addition to these sessions, pre-test measurements were collected from the participants before the experimental process. Next, the post-test measurements were applied immediately after the last session of the experimental procedure. The application was carried out in a group counseling room. There was a total of six sessions; each session lasted for $90 \mathrm{~min}$ and was held between 14.00 and 15.50 each Thursday. These sessions were carried out by the researchers.

\section{Data collection tools}

Career counseling competences and performance indicators scale

In this scale developed by the USA NCDA (1997), there are a total of 11 competency areas, with indicators of each area. The scale is a three-point scale $(1=$ inadequate, 2 = partially adequate, $3=$ adequate). In the current study, just three competency areas were addressed. These comprised skills of counseling with an individual and a group, individual and group evaluation, and career information/sources. In the data analysis process, the total scores from these three competency areas were used. The total score range of the scale (out of the three dimensions considered) ranged between 27 and 81 . Finally, a reliability study was conducted on its own study group using the internal consistency

Table 2 Content of the STEM career maturity program

\begin{tabular}{|c|c|c|c|c|}
\hline Sessions & Activities & Aims & Objectives & Corresponding dimension \\
\hline $\begin{array}{l}\text { First } \\
\text { session }\end{array}$ & $\begin{array}{l}\text { Introducing } \\
\text { and structuring }\end{array}$ & Ensure group harmony & $\begin{array}{l}\text { Collect information about the program } \\
\text { and process }\end{array}$ & - \\
\hline $\begin{array}{l}\text { Second } \\
\text { session }\end{array}$ & $\begin{array}{l}\text { Professional } \\
\text { development } \\
\text { meeting about } \\
\text { STEM }\end{array}$ & $\begin{array}{l}\text { Make them realize conscious orientation } \\
\text { towards the choice a STEM profession } \\
\text { and collect information about STEM } \\
\text { professions }\end{array}$ & $\begin{array}{l}\text { Realize the importance of being able to } \\
\text { make STEM career and develop his/her } \\
\text { knowledge base on STEM professions }\end{array}$ & $\begin{array}{l}\text { Conscious orientation towards } \\
\text { the choice of a STEM profession } \\
\text { and collecting information about } \\
\text { STEM professions }\end{array}$ \\
\hline $\begin{array}{l}\text { Third } \\
\text { session }\end{array}$ & $\begin{array}{l}\text { Research about } \\
\text { STEM-centered } \\
\text { professions }\end{array}$ & Foster the exploration of a STEM career & $\begin{array}{l}\text { Investigate the consistency of his/her } \\
\text { preference for a STEM profession in terms } \\
\text { of the fields and levels of professions }\end{array}$ & $\begin{array}{l}\text { Consistency of the choice of a } \\
\text { STEM profession }\end{array}$ \\
\hline $\begin{array}{l}\text { Fourth } \\
\text { session }\end{array}$ & $\begin{array}{l}\text { Discover their } \\
\text { suitability for } \\
\text { STEM } \\
\text { professions }\end{array}$ & Foster the exploration of a STEM career & $\begin{array}{l}\text { Evaluate the suitability of the fields of } \\
\text { STEM professions for self-concepts }\end{array}$ & $\begin{array}{l}\text { Clarification of the characteristics } \\
\text { related to STEM professions }\end{array}$ \\
\hline $\begin{array}{l}\text { Fifth } \\
\text { session }\end{array}$ & $\begin{array}{l}\text { Directed } \\
\text { fantasy }\end{array}$ & Enhance the plan of a STEM career & $\begin{array}{l}\text { Establish connections between the choice } \\
\text { of a STEM profession and his/her } \\
\text { interests, abilities, and the activities that } \\
\text { he/she will be engaged in }\end{array}$ & $\begin{array}{l}\text { Rationality in the preference for a } \\
\text { STEM profession }\end{array}$ \\
\hline $\begin{array}{l}\text { Sixth } \\
\text { session }\end{array}$ & Evaluation & Evaluate the process of the program & $\begin{array}{l}\text { Evaluate the effectiveness of the career } \\
\text { maturity program }\end{array}$ & - \\
\hline
\end{tabular}


coefficient method. The internal consistency coefficient was found to be 0.90 .

\section{Focus group interviews}

At the end of the career maturity program, the participants were divided into groups of five, in line with the criteria to be determined, and focus group discussions were held. Focus group interviews are defined as the process of obtaining in-depth information and producing thoughts through the use of group dynamics between a group and the researcher conducting the interview (Bowling, 2002). Focus group interviews are a qualitative data collection technique that has been frequently used in experimental studies (Krueger \& Casey, 2000). The main purpose of using focus group interviews within the context of the current study was to allow the participants to express their thoughts in a comfortable environment (Krueger \& Casey, 2000) and share their independent and common experiences during the program. Thus, through these experiences, what the program meant for the participants and how effective they found it to be were evaluated.

\section{Data analysis}

\section{Quantitative data analysis}

The pre-test analyses were conducted first. For these analyses, the normality assumption for the pretest scores was tested using the Shapiro-Wilk test, wherein it was found that $P=0.00$. This value showed that the data were not distributed normally. Therefore, the data were analyzed using non-parametric statistical techniques and in this regard, the Mann-Whitney $U$ test was used to determine whether there were significant differences between the pretest scores and posttest scores of the experimental and control groups, while the Wilcoxon signed-ranks test was used to determine whether there was a significant difference between the pretest and posttest measurements of the experimental and the control group, and the direction of the difference (Buyukozturk, 2009).

\section{Qualitative data analysis}

Using an inductive approach, the qualitative data were analyzed using the content analysis method. The analysis of the qualitative data was carried out in four main processes, comprising (i) coding the data, (ii) creating the themes (categories), (iii) arranging the codes and themes, and (iv) defining and interpreting the findings (Corbin \& Strauss, 2015). In the data analysis process, coding was performed by the individual researchers, and the obtained results were compared to establish the validity and reliability of the study. In the qualitative dimension of the study, in order to improve the internal validity, participant confirmation, direct quotations, and long- term interactions were capitalized on, while a detailed description of the characteristics of the participants, application process, and data collection and analysis processes was provided in order to improve the external validity. In addition, the data triangulation method was followed to control the consistency of both the qualitative and quantitative data.

\section{Results \\ Quantitative findings}

In this section, the descriptive statistics of the pre-test and post-test results of the experimental and control groups are discussed. Table 3 presents the MannWhitney $U$ pre- and post-test results of the experimental and control groups, as well as the Wilcoxon signedranks test results for the pre- and post-tests measurements of the experimental and control groups.

When the pre-test findings presented in Table 3 are examined, it can be seen that while the mean CCCPI scale score of the experimental group was 64.85 , that of the control group was 68.57. On the other hand, when the post-test findings are examined, it can be seen that while the mean CCCPI scale score of the experimental group was 73.21, that of the control group was 68.28.

As presented in Table 4, there was no significant difference between the pre-test mean CCCPI scale scores of the experimental and the control groups $(U=87.50$, $P>0.05)$. The average rank of the experimental group was 13.75 , whereas in the control group, it was 15.25 . This finding showed that before the experimental application, the experimental and control groups were equal.

As seen in Table 5, there was a significant difference between the post-test mean CCCPI scale scores of the experimental and control groups $(U=49.00, P<0.05)$. The average rank of the experimental group was 18.00 , whereas in the control group, it was 11.00. Moreover, the CCCPI scale mean rank and sum of mean scores of the experimental group were higher than those of the control group. This finding showed that the STEM career maturity program was effective in terms of improving the CCCPI in the experimental group.

Table 6 shows that the mean CCCPI scale scores of the experimental group increased after the experimental application $(Z=-3.07, P<0.01)$. The mean negative rank sign was 1.75 , while the mean positive rank sign was 8.46. This finding proved that the STEM career

Table 3 Descriptive statistics of the CCCPI scale in the experimental and control groups

\begin{tabular}{llllll}
\hline Groups & Pre-test & & & Post-test & \\
\cline { 2 - 3 } \cline { 6 - 6 } & $\mathbf{M}$ & SD & & M & SD \\
\hline Experimental & 64.85 & 7.97 & & 73.21 & 5.29 \\
Control & 68.57 & 1.97 & & 68.28 & 6.05 \\
\hline
\end{tabular}


Table 4 Findings obtained from the Mann-Whitney $U$ pre-test in the experimental and control groups.

\begin{tabular}{lllllll}
\hline Scale & Group & $\boldsymbol{N}$ & Mean rank & Sum of mean & $\boldsymbol{U}$ & $\boldsymbol{P}$ value \\
\hline CCCPI & Experimental & 14 & 13.75 & 192.50 & 87.50 & 0.62 \\
& Control & 14 & 15.25 & 213.50 & & \\
\hline **P<0.01 *P<0.05 & & & & &
\end{tabular}

maturity program was effective in increasing the CCCPI scale scores of the students. Moreover, the effect size was also calculated and was found to be 0.58 . This value showed that the experimental application had a large effect size. As a result, these findings statistically proved the effectiveness of the program.

Table 7 indicates that there was no significant difference between the pre- and post-test mean CCCPI scale scores of the control group $(Z=-0.03, P>0.05)$.

\section{Qualitative findings}

Four themes were selected as a result of the analysis of the qualitative data, comprising (1) personal and professional development, (2) awareness of the STEM majors and careers, (3) STEM-focused career counseling, and (4) feedback about the program.

\section{Personal and professional development}

The participants emphasized at different points that the training that they had received contributed to their personal and professional development. One of the most important contributions was the change in their perception of interdisciplinary activities. The participants stated that their experiences during the program made a positive contribution to going outside of their field and increasing their motivation towards other disciplines. As can be seen in the excerpt given below, a participant who had a negative attitude towards fields such as engineering before the program, stated that at the end of the process, he started to think about what kind of interdisciplinary relationship could be established between his field and these fields.

"What I have learned is that you, three people, from different fields are coming together and providing this training for us. When I think of how STEM can be relevant to me, I can understand this when I see you; there is a cooperation between different disciplines and this can contribute to development.

Table 5 Findings obtained from the Mann-Whitney $U$ post-test in the experimental and control groups

\begin{tabular}{lllllll}
\hline Scale & Group & $\boldsymbol{N}$ & Mean rank & Sum of mean & $\boldsymbol{U}$ & $\boldsymbol{P}$ value \\
\hline CCCPI & Experimental & 14 & 18.00 & 252.00 & 49.00 & $0.02^{*}$ \\
& Control & 14 & 11.00 & 154.00 & & \\
\hline
\end{tabular}

${ }^{*} P<0.01,{ }^{*} P<0.05$
Table 6 Findings obtained from the pre- and post-test Wilcoxon signed-ranks test in the experimental group

\begin{tabular}{lllllll}
\hline Scale & Rank sign & $\boldsymbol{N}$ & Mean rank & Sum of mean & $\boldsymbol{Z}$ & $\boldsymbol{P}$ value \\
\hline CCCPI & Negative & 2 & 1.75 & 3.50 & -3.07 & $0.00^{* *}$ \\
& Positive & 12 & 8.46 & 101.50 & & \\
& Equal & 0 & & & & \\
${ }^{* * P} \boldsymbol{P}<0.01,{ }^{*} \boldsymbol{P}<0.05$ & & & & &
\end{tabular}

Moreover, I was not very interested in the field of engineering, but now I have realized that this is very important for the development of countries, so we need to think about it."

Another point that the participants thought contributed to their professional development was that they gained awareness of the need to adapt to the developing world through current approaches. During the training process, many participants questioned the currency and applicability of what they had learned in the changing world. For example, one of the participants stated that she understood that she needed to improve herself more in order to gain up-to-date knowledge and competencies in her field as a result of the project.

"I realized that I had to improve myself a little more. I think that we should leave some traditional ways behind us and work in a more modern way to progress in the field."

When the findings of the current study were examined, it was seen that the participants did not find the support that they had received in the context of a STEM career to be adequate or up-to-date. For example, a participant criticized that it was not possible for them to predict the future by questioning the adequacy of the career-centered measurement tools used in the field.

"The measurement tests we learned are from old times, we are directing students towards their future occupations, and we measure their skills, but as professional identity, I also learned that the psychological counsellor should be able to predict the future. I think this will happen as we work, I do not

Table 7 Findings obtained from the pre- and post-test Wilcoxon signed-ranks test for the control group

\begin{tabular}{cllllll}
\hline Scale & Rank sign & $\boldsymbol{N}$ & Mean rank & Sum of mean & $\boldsymbol{Z}$ & $\boldsymbol{P}$ value \\
\hline CCCPI & Negative & 8 & 6.63 & 53.00 & -0.03 & 0.97 \\
& Positive & 6 & 8.67 & 52.00 & & \\
& Equal & 0 & & & & \\
${ }^{* * P}<<0.01,{ }^{*} P<0.05$ & & & &
\end{tabular}


know how this can be predicted right now, but a psychological counsellor should also be able to predict the future."

Another participant shared his belief that the theories that they had learned about their field would not be sufficient to explain the situations within the context that they were in, since these theories were those that had been put forward in the past. In addition, he noted that he had doubts about the extent to which existing theories could be adapted to new conditions and that he thought that problems might arise in this regard, especially as the STEM approach becomes widespread in their field.

"In general, the theories or scientific developments about which the training that we received were dated back to the 1950s. However, we will graduate in 2020, so how well can we adapt them to 2030 to 2040, or should we adapt them? I have some doubts about this because the field of STEM seems to be in our profession."

Another point stated by the participants who gained awareness in terms of the contributions to their professional development, was the desire to renew and improve themselves. The participants stated that they needed continuous improvement in terms of accomplishing professional development by saying "We know that professional development and career are not static." The participants remarked that they thought that they should carry out continuous research in order to achieve this development.

"As I said, I do not think that professional or career counselling was very good. After the six-week training, I realized that there were actually other areas of profession that need to be researched. I realized that professionally, I actually needed to do more research and not to remain where I am."

Pointing to the importance of continuous research to improve themselves, the participants emphasized the importance of following the occupational branches that have changed and been updated over the years in terms of career counseling. Therefore, they emphasized competencies such as innovative thinking and staying up-todate in order to perform career counseling during the process.

"From the new information I have learned here, for example about STEM fields, I remember very clearly that the future professions are updated and changed every five years; that is, I have learned that when I am asked by a client about future professions, I should continuously follow the developments and changes in the professions before giving information. I once again understood that I need to constantly think innovatively, which was the professional contribution of the program for me."

In this context, another remarkable point was the changes that participants saw in themselves during the program. Before the program, they thought that they themselves, as the psychological counselors were inadequate, while they thought that they had developed themselves in a way that could help students during the process.

"Before STEM, I thought we were staying a bit simpler; as a result of my observations, I also thought that school counsellors were also inadequate, but now I think I have developed more in this regard through the STEM training, and I think I can better help my students."

The last point put forward by the participants in terms of the contribution to their professional development was professional roles and responsibilities. In the focus group discussions, the participants stated that they realized that the professional roles and responsibilities changed over time, and that their predictions about the direction of this change had developed. For example, one participant stated that traditionally, career counseling has had a point-based orientation approach and emphasized that the process should be managed in line with the realities of the changing and developing world.

"When we are a psychological counselling teacher at a school, I believe that it will be better to encourage or direct the student to research future professions and it is not good to direct them on the basis of their grade point averages or ranking."

Another participant stated that through the training given within the project, she realized that the role of the psychological counselor in the career counseling process was as a catalyst among the interests and abilities of the students.

"As psychological counsellors, we need to be interested in what students like to do with their talents and interests, and I realized that we stand as catalysts among them, as you said."

Finally, it was revealed that the predictions of the participants about which direction their fields would evolve in, in line with the developing technology, had changed. 
They proposed predictions about how career counseling would be transformed along with the developing technology. For example, one of the participants stated that her negative perception towards the transformation of consultancy along with the developing technology changed during the project, and she increased her motivation to make an effort to prepare herself for this transformation.

"There was an issue we were discussing here, where there was a study we did with students from the Department of Computer and Instructional Technologies Education about how far we can go with psychological counselling. But there I objected a little bit and still do. I said that the information received from a person and the consultation given by a machine on the other side would be different. I'm still of the same opinion, but it's something that can thrive. If everyone thinks that psychological counselling will not improve, we will definitely not contribute to it. So I am planning to change my mind."

\section{Awareness of the STEM majors and careers}

One of the themes that emerged as a result of the analysis of the data obtained from the focus group interviews was the information about the STEM professional fields. The participants stated that within the scope of the STEM approach, their knowledge and awareness of professional areas had increased. Moreover, they stated that they realized what professions were expected to come to the forefront in the future. One of the participants expressed this as follows:

"I didn't know much about STEM before coming here. I had not even heard of its name before. After I came here, I learned about STEM and this raised my awareness about the professions of the future; that is, about engineering."

The findings revealed that the knowledge and awareness of the participants about the professions changed during the process. In this context, one of the participants stated that they gained different perspectives about the professions that existed in this process when compared to their prior knowledge.

"We had different perspectives about professions; here our perspective about future professions of STEM has changed. We realized that some of the professions that are currently known in society actually have different aspects than what is known in society."
Another important finding under this theme was that the traditional perspective of the participants about the professions had changed and turned into an interdisciplinary approach. The participants, who became aware of the STEM approach and the transformation that this approach has brought about in the professions, suggested many times that the skills and competencies required by the professions should be handled in an integrated manner. As seen in the example below, the participant argued that he learned to approach professions in a multidisciplinary way by the end of the participatory process.

"During this process, I actually learned to look at professions from a multidisciplinary perspective, which was called STEM. I also learned how to look at the issue from individual and social perspectives."

\section{STEM-focused career counseling}

Another theme obtained as a result of the analysis of the statements of the participants in the focus group interviews was named STEM-focused career counseling. Under this theme, it was revealed how the participants made sense of the STEM career counseling in the process. Being aware of the promising areas of the future within the scope of career counseling, the participants underlined the importance of informing young people about these areas.

"Of course, we will direct them to an area that suits their personality, self, and abilities. However, we also need to know the needs of the future or the areas that students need to be directed to, so that we can direct our students correctly. At this point, I think that we need to know the strategic point in our profession and we need to continuously follow the developments."

On the other hand, it was observed that the participants who did not know about the STEM approach before the project or who thought that they were not related to its fields had gained awareness of the points where this approach intersected with the fields. It was stated that the benefits of the STEM approach for the participants in terms of career counseling were realized.

"I have seen STEM in a few places, but generally, I saw it as an activity that science teachers implemented in the classroom, and I think that it cannot be adapted much in our profession because in general, it includes activities directed toward science and mathematics. However through the project, I have learned that it can contribute to our profession. We have seen what contribution career counselling can make for us and how we can progress in this regard." 
"I realized that we need to improve ourselves as a psychological counsellor and what the relationship between career counselling and STEM is."

As a result of the awareness that they gained during the process, it was observed that the participants were more interested in the STEM career issue and as a result, they tended to do more research on the subject. During the focus group interviews, the participants showed their interest in the subject by sharing the information that they had obtained as a result of their research. One of the participants stated that he saw that there was a gap in the area related to this subject and therefore, it would be wise to be directed towards this area.

"In this area, there is a gap in general, because applications related to STEM are not carried out too often. This attracted my attention. Maybe our future research will be in this direction."

After gaining knowledge and awareness of the STEM career counseling process, the participants adopted a critical perspective about their fields, and their practices transformed accordingly. Therefore, they stated that their negative attitudes and judgments towards the field also changed during this process. For example, one of the participants stated that the reason for his negative judgments about career counseling was the traditional methods, and that he realized during the project that the content in the field is highly rich and as a result, he developed a more positive perspective of career counseling.

"As for its relationship with career counselling, it was a distant field for me. I didn't like career counselling or occupational counselling, because I thought it was too simple. Apply test, apply inventory, then direct the student, but here, I realized that there are different professional fields in STEM and that career counselling does not actually consist of the threesession process of applying a test, an inventory, and directing. Rather, it has a richer content."

\section{Feedback about the program}

The data obtained from the focus group interviews also revealed the opinions of the participants regarding the program. In this context, although the participants saw this process as an important experience in terms of gaining knowledge and awareness, they also put forward some suggestions that will make this experience more productive. The first of these suggestions was to enrich the content by spreading the process over a longer-term. The participants argued that knowledge and awareness could be transferred to experience in this way. One of the participants expressed this as "we gained awareness, but I am lacking in how we can apply it." Another participant argued that knowledge can become more permanent by gaining experience on the subject.

\section{"I also think it is good, as information was presented and ideas were exchanged, but I think applications, images, and videos could be used to make the infor- mation permanent."}

Similarly, another participant stated that the project did not promise an experience-oriented process; thus, non-experiential information was not permanent and this situation emerged as a deficiency.

"We were told at the beginning that it would be didactic, not experiential. I did not come with an expectation of learning practical information. Frankly, I came to learn information on my behalf, but some information cannot be permanent unless it is experiential."

Another suggestion put forward by the participants to improve the process was that the process was not supported by adequate resources. Despite sharing online resources with the participants in the process, a participant who found herself more likely to benefit from traditional printed resources stated that she could have followed the process more efficiently with concrete documents.

"The missing thing was documents... we did not have any documents, you were teaching something, but we only followed just as listeners. If had had some documents, I could have followed the subject better and when I went home, I could have revised the documents."

Another participant emphasized that as a result of a learning process in which the currency of the tests and scales used in the field of career counseling was questioned, it was necessary to provide the participants with more up-to-date tests and scales.

"We talked about scales; scales produced in the past. It was said that there was no up-to-date scale. No new scales have been developed. Now we do not have scales, but which resources can we reach?"

Another suggestion was to integrate technology into the learning process. The participants stated that carrying out technology-supported activities during the process could be an important step in increasing the efficiency of the process. Stating that these applications 
could be presented via videos in cases where the application was not possible, the participant suggested that the process could be enriched to the extent permitted by the participatory conditions.

"For example, there were some examples of stem areas we talked about here and we gave some examples of their adaptation to our field. It would be nice to have their applications shown here or it would be more effective to do video-supported activities. Video-supported, computer-aided activities, maybe tablet-supported activities, but I do not know how much the conditions will allow."

The last finding obtained from focus group interviews within the scope of this theme was on the role of intrinsic and extrinsic motivation. A participant criticizing the fact that the learning process was completely based on professional gains argued that the issue of intrinsic motivation was overlooked to a great extent.

"This gave us extrinsic motivation, instead, this document might not have been emphasized that much. I think it would have been more beneficial if education had been emphasized more, thus, people would have had intrinsic motivation."

\section{Discussion}

When the literature was examined, it was observed that studies have mostly been conducted on the effectiveness of career maturity programs (Esters \& Retallick, 2013; Karatas \& Yavuzer, 2009; Shdaifat, 2019). However, research on the effectiveness of the STEM career maturity program is limited. Thus, as the current study has revealed findings on a less studied subject, it contributes to the literature. In addition, because the qualitative data were used to explain the quantitative data in more detail and depth (Creswell, 2013), the effect of the STEM career maturity program on the perspectives of the participants has been better elicited. Hence, the detailed and comprehensive data presented in the current study is the strength of the study.

In the literature, there are studies on STEM careers (Holmes et al., 2018; Kiriktas \& Sahin, 2019; LaForce et al., 2017; Miller et al., 2018) and scale development and adaptation studies (Kier et al., 2014; Shin et al., 2016; Tyler-Wood et al., 2010). On the other hand, there is a serious paucity of experimental studies on STEM careers. Thus, research to be conducted on the effectiveness of STEM career maturity can make important contributions to the literature.

In the quantitative findings of this study, it was revealed that the STEM career maturity program enabled the pre-service psychological counseling teachers to show positive developments in the CCCPI. The reason for this can be found in the content of the STEM career maturity program. In this program, psycho-educationbased skill acquisition, career counseling techniques, and literature-based interventions enabled the pre-service psychological counseling teachers to obtain knowledge about the STEM profession areas, realize the importance of STEM career choices, gain awareness of the necessary theoretical and practical knowledge and skills in relation to STEM career counseling, and increase their level of competence in STEM career maturity.

When the data obtained from the focus group interviews conducted within the scope of the study were examined, it was observed that the participants displayed a skill-oriented approach in terms of career orientation. To be more specific, it was emphasized that the skill and competency sets required by professions that have come to the forefront, or that have potential to come to the forefront in the twenty-first century, should form the basis of the STEM education approach. Skills such as problem solving, systematic thinking, leadership, teamwork, and entrepreneurship, which are at the center of the STEM education approach, constitute the competencies of the professions necessary for the development of countries in global competition (Bybee, 2010; Roberts, 2012). Therefore, the statements of the participants showed that they have drawn an appropriate path to the STEM approach within the scope of career counseling. The fact that the skills and competencies were brought to the forefront by the participants showed that the program was successful, considering its structure and objectives.

Knowledge of STEM is not just essential due to market demand, it is also important in the adequate preparation of students in the knowledge and skills that will be required for them to contribute as citizens in twentyfirst century society, which will be both information and technologically rich (Crotty, 2018). As STEM fields continue to grow, there is a concern that students will not be ready to enter a workforce and they will face many unforeseen challenges (Adams et al., 2014). For this reason, it is extremely important that psychological counselors provide skill-oriented guidance to students in order for students to achieve success in these promising but unpredictable fields. As a result of the program implemented herein, the participants exhibited similar views and emphasized skills and competency-based approaches in career and occupational counseling, confirming that the program was consistent with the arguments proposed in the literature.

Super's (1980) career maturity model, which constituted the theoretical framework of the program implemented in the current study, showed that the 
concept of career maturity reflects the readiness level of individuals for a profession and underlines the importance of this concept in the choice of a profession. The findings obtained from the qualitative data showed that the participants gained awareness of the importance of career maturity in choosing a career, in the context of STEM. The participants emphasized the necessity of informing students and making them qualified to choose a profession, rather than directing them to a profession on the basis of their academic achievement by dictating or forcing them, which showed that they grasped the essence of career maturity. The fact that this understanding, which formed the basis of the theoretical framework of the program, was exhibited by the participants was of critical importance for the program to achieve its goals.

One of the biggest obstacles to the success of the STEM education approach is the lack of professional development opportunities for a sufficient number of educators to increase their interest and competence in STEM fields (Jeffery et al., 2015). This also prevents future teachers from developing a STEM identity and thus, taking steps in this direction (Adams et al., 2014). It is obvious that this situation is more critical for psychological counselors and guides who are directly responsible for the career maturity and career choices of students. The effects of the program developed within the current study on the participants were revealed through both quantitative and qualitative data, and this was very important to shed light on future programs that can be developed and implemented.

\section{Conclusions}

The general purpose of the current study was to examine the effectiveness of the STEM career maturity program prepared for fourth-year students of the counseling undergraduate program. According to the quantitative findings of the study, it was found that the developed program increased the CCCPI scale scores of the pre-service counseling teachers. The qualitative findings revealed the evaluations of the participants regarding the effects of the application process on their professional development, their knowledge and awareness of STEM professional areas, and STEM-focused career counseling competencies. The STEM career maturity program, which was developed based on Super's (1974) career maturity model, met the objectives, as both the statistical results and the statements of the participants indicated. The literature revealed that certain variables have often been found to contribute to the success of professional development programs. These variables include, but are not limited to, time, content, activities, workshops, and outside experts (Guskey and Yoon 2009). Using these features as the basis of the program implemented in this study, the researchers found positive impacts on the CCCPI scale scores of the participants, as well as their knowledge and awareness of professional STEM areas.

The reform documents around the STEM education movement highlight the significance of early intervention in the STEM career choices of students to increase their awareness of pursuing STEM careers. These documents also address the insufficient awareness of the students about STEM fields and their lack of knowledge regarding the relationship between these fields and their abilities. Considering the role of school counselors in supporting students in choosing STEM careers, the STEM career maturity program designed and implemented in this study provides a strong model for supporting pre-service and in-service school counselors in directing students toward STEM fields, so as to develop a qualified workforce in STEM fields, which is one of the main objectives of STEM education movement.

\section{Abbreviations}

STEM: Science, Technology, Engineering, and Mathematics; TUSIAD: Turkish Industry and Business Association; NCDA: National Career Development Association; CCCPI: Career Counseling Competencies and Performance Indicators

\section{Acknowledgements}

This study was made possible by the Scientific Research Projects Commission. The findings, conclusions, and opinions herein represent the views of the authors and do not necessarily represent the view of personnel affiliated with the commission.

\section{Authors' contributions}

All authors contributed to the data collection, analysis, and writing of the paper. The author(s) read and approved the final manuscript.

Funding

Not applicable

\section{Availability of data and materials}

The data sets and interview recordings are deposited in repositories located in the public university. The data generated and analyzed during the current study are available anonymized from the corresponding author by request.

\section{Declarations}

Ethics approval and consent to participate

All of the procedures performed in studies involving human participants were in accordance with the ethical standards and the Helsinki Declaration and its later amendments or comparable ethical standards.

\section{Consent for publication}

Informed consent was obtained from all of the individual participants included in the study. The authors did not receive any financial support for the research, authorship, and/or publication of this article.

\section{Competing interests}

The authors declare that they have no competing interests.

\section{Author details}

${ }^{1}$ Department of Curriculum and Instruction, Eskisehir Osmangazi University, Eskisehir, Turkey. ${ }^{2}$ Department of Psychological Counseling and Guidance, Eskisehir Osmangazi University, Eskisehir, Turkey. ${ }^{3}$ Department of Elementary Education, Eskisehir Osmangazi University, Eskisehir, Turkey. 
Received: 3 October 2020 Accepted: 22 February 2021

Published online: 31 March 2021

\section{References}

Adams, A. E., Miller, B. G., Saul, M., \& Pegg, J. (2014). Supporting elementary preservice teachers to teach STEM through place-based teaching and learning experiences. Electronic Journal of Science Education, 18(5), 1-22 http://ejse. southwestern.edu/article/view/12958.

Akgunduz, D. (2016). A research about the placement of the top thousand students placed in STEM fields in Turkey between the years 2000 and 2014. EURASIA Journal of Mathematics, Science and Technology Education, 12(5), 1365-1377. https://doi.org/10.12973/eurasia.2016.1518a.

Archer, L., DeWitt, J., Osborne, J., Dillon, J., Willis, B., \& Wong, B. (2014). ASPIRES: Young people's science and career aspirations, age 10-14. London: Kings College London, Department of Education \& Professional Studies.

Ayas, T., Deniz, M., Kagan, M., \& Kenc, M. F. (2010). An investigation of conflict resolution strategies of adolescents. Procedia-Social and Behavioral Sciences, 2(2), 3545-3551. https://doi.org/10.1016/j.sbspro.2010.03.549.

Bowling, A. (2002). Research methods in health: investigating health and health services. Buckingham: Open University Press.

Brown, N. W. (2004). Psychoeducational groups process and practice. New York: Brunner-Routledge.

Buyukozturk, S. (2009). Sosyal bilimler için veri analizi el kitabı [Data analysis handbook for social sciences]. Ankara: Pegem. https://doi.org/10.14527/ 9789756802748.

Bybee, R. (2010). Advancing STEM education: a 2020 vision. Technology and Engineering Teacher, 70(1), 30-35.

Bybee, R. W. (2013). A case for STEM education. Arlington: National Science Teachers' Association Press.

Corbin, J., \& Strauss, A. (2015). Basics of qualitative research, (4th ed., ). Thousand Oaks: Sage.

Creed, P. A., \& Patton, W. (2003). Predicting two components of career maturity in school-based adolescents. Journal of Career Development, 29(4), 277-290. https://doi.org/10.1177/089484530302900405

Creswell, J. W. (2013). Steps in conducting a scholarly mixed methods study. Lincoln: Digital Commons @ University of Nebraska.

Crites, J. O. (1969). Vocational psychology. New York: McGraw-Hill.

Crites, J. O. (1971). The maturity of vocational attitudes in adolescence. Vocational Guidance Quarterly, 20(1), 82-82. https://doi.org/10.1002/j.2164-585x.1971.tb02 014.x.

Crotty, E. (2018). Understanding the ways in which teacher leadership teams influence STEM integration in emerging STEM schools. [Unpublished doctoral dissertation]. University of Minnesota Twin Cities.

Ejiwale, J. (2013). Barriers to successful implementation of STEM education. Journal of Educational Learning, 7(2), 63-74. https://doi.org/10.11591/edulea rn.v7i2.220.

Epstein, D., \& Miller, R. T. (2011). Slow off the market: elementary school teachers and the crisis in STEM education. Education Digest, 77(1), 4-10.

Esters, L., \& Retallick, M. (2013). Effect of an experiential and work-based learning program on vocational identity, career decision self-efficacy, and career maturity. Career and Technical Education Research, 38(1), 69-83. https://doi. org/10.5328/cter38.1.69.

Guskey, T. R., \& Yoon, K. S. (2009). What works in professional development? Phi Delta Kappan, 90(7), 495-500. https://doi.org/10.1177/003172170909000709.

Herr, E. L., Cramer, S. H., \& Niles, S. G. (2004). Career guidance and counseling through the lifespan-systematic approaches. Boston: Allyn \& Bacon.

Hirsch, L. S., Carpinelli, J. D., Kimmel, H., Rockland, R., \& Bloom, J. (2007). The differential effects of pre-engineering curricula on middle school students' attitudes to and knowledge of engineering careers. Milwaukee: Published in the proceedings of 2007 Frontiers in Education Conference.

Holmes, K., Gore, J., Smith, M., \& Lloyd, A. (2018). An integrated analysis of school students' aspirations for STEM careers: Which student and school factors are most predictive? International Journal of Science and Mathematics Education, 16(4), 655-675. https://doi.org/10.1007/s10763-016-9793-z.

Honey, M., Pearson, G., \& Schweingruber, H. (2014). STEM integration in K-12 education: Status, prospects, and an agenda for research, (vol. 500). Washington, DC: National Academies Press.

Jeffery, T. D., McCollough, C. A., \& Moore, K. (2015). Growing STEM roots: preparing pre-service teachers. Academic Exchange Quarterly, 19(3), 102 https://scholarworks.sfasu.edu/elementaryed_facultypubs/41/.
Karahan, E. (2020). Investigating STEM-focused instructional module designs of engineering students. Bogazici University Journal of Education, 37, 73-91.

Karatas, Z., \& Yavuzer, Y. (2009). Yaratıcı drama temelli mesleki grup rehberliğinin lise öğrencilerinin mesleki olgunluk puanlarına etkisi [Effects of group guidance based on creative drama on vocational maturity scores of students in high school]. Educational Sciences and Practice, 8(15), 83-98. https://doi. org/10.14527/9786054282838.04.

Kelley, T. R., \& Knowles, J. G. (2016). A conceptual framework for integrated STEM education. International Journal of STEM Education, 3(1), 1-11. https://doi. org/10.1186/s40594-016-0046-Z

Kidd, J. M. (2006). Understanding career counselling theory: research and practice. London: Sage.

Kier, M. W., Blanchard, M. R., Osborne, J. W., \& Albert, J. L. (2014). The development of the STEM career interest survey (STEM-CIS). Research in Science Education, 44(3), 461-481. https://doi.org/10.1007/s11165-013-9389-3.

Kiriktas, H., \& Sahin, M. (2019). Lise öğrencilerinin STEM alanlarına yönelik kariyer ilgileri ve tutumlarının demografik değişkenler açısından incelenmesi [An investigation of career attitudes and attitudes of high school students towards stem areas in terms of demographic variables]. Academia Eğitim Araştırmaları Dergisi, 4(1), 55-77. https://doi.org/10.29000/rumelide.752051.

Krueger, R. A., \& Casey, M. A. (2000). Focus groups: a practical guide for applied research. California: SAGE.

Kuzgun, Y. (2003). Meslek rehberliği ve danışmanlığına giriş [Introduction to career counselling and guidance]. Ankara: Nobel.

LaForce, M., Noble, E., \& Blackwell, C. (2017). Problem-based learning (PBL) and student interest in STEM careers: The roles of motivation and ability beliefs. Education and Science, 7(4), 92. https://doi.org/10.3390/educsci7040092.

Miller, K., Sonnert, G., \& Sadler, P. (2018). The influence of students' participation in STEM competitions on their interest in STEM careers. International Journal of Science Education, Part B, 8(2), 95-114. https://doi.org/10.1080/21548455.2 017.1397298

Moore, T., \& Richards, L. G. (2012). P-12 engineering education research and practice. Advances in Engineering Education, 3(2), 1-9.

National Academy of Engineering (2009). Engineering in K-12 education: understanding the status and improving the prospects. Washington, DC: National Academies Press.

National Academy of Sciences (2006). Rising above the gathering storm: Energizing and employing America for a brighter economic future. Washington, DC: National Academies Press.

National Career Development Association [NCDA] (1997). NCDA guidelines for the use of the Internet for provision of career information and planning services. Columbus: Author.

National Research Council (2011). Successful K-12 STEM education: identifying effective approaches in science, technology, engineering, and mathematics. Washington, DC: The National Academies Press.

Noonan, R. (2017). STEM jobs: 2017 update. ESA issue brief \#02-17. Washington, DC: U.S. Department of Commerce, Economics and Statistics Administration, Office of the Chief Economist.

Patton, M. Q. (2014). Qualitative research \& evaluation methods: integrating theory and practice. Thousand Oaks: Sage Publications.

Rinn, A. N., \& Kettler, T. (2020). Assessing and developing diverse STEM talent: Introduction to the special issue. Journal of Advanced Academics, 31(3), 159-160.

Roberts, A. (2012). A justification for STEM education. Technology and Engineering Teacher, 71(8), 1-4.

Savickas, M. L. (1984). Career maturity: the construct and its assessment. Vocational Guidance Quarterly, 22, 222-231. https://doi.org/10.1002/j.2164585x.1984.tb01585.x.

Savickas, M. L., Briddick, W. C., \& Watkins Jr., C. E. (2002). The relation of career maturity to personality type and social adjustment. Journal of Career Assessment, 10(1), 24-49. https://doi.org/10.1177/1069072702010001002.

Shdaifat, S. (2019). The impact of a proposed vocational guidance program on the vocational maturity and interest of tenth (10th) grade students in Jordan. International Journal of Education, Learning and Development, 7(3), 92-110 http://zujournal.zu.edu.jo/images/stories/2019/vol1/1.pdf.

Shin, S., Ha, M., \& Lee, J. K. (2016). The development and validation of instrument for measuring high school students' STEM career motivation. Journal of the Korean Association for Science Education, 36(1), 75-86. https://doi.org/10.14 697/jkase.2016.36.1.0075.

Spencer, M. E. (2011). Engineering perspectives of grade 7 students in Canada (Unpublished master's thesis). Queen's University. 
Super, D. E. (1974). Measuring vocational maturity for counseling and evaluation. Washington, DC: American Personnel and Guidance Association.

Super, D. E. (1980). A life-span, life-space approach to career development. Journal of Vocational Behavior, 16(3), 282-298. https://doi.org/10.1016/000|8791/80/030282-17\$02.00

Super, D. E., \& Knasel, E. G. (1981). Career development in adulthood: some theoretical problems and a possible solution. British Journal of Guidance and Counselling, 9(2), 194-201. https://doi.org/10.1080/03069888108258214.

Super, D. E., \& Nevill, D. D. (1984). Work role salience as a determinant of career maturity in high school students. Journal of Vocational Behavior, 25, 30-44. https://doi.org/10.1016/0001-8791(84)90034-4.

Super, D. E., \& Overstreet, P. L. (1960). The vocational maturity of ninth grade boys. New York: Teachers College Press.

Turkish Industry and Business Association (TUSIAD). (2017). 2023'e dogru Turkiye'de STEM gereksinimi [Need for STEM in Turkey towards 2023]. Resource document. TUSIAD. https://tusiad.org/tr/tum/item/download/8649_ 50851324e41c6e46cab3e6ea3b37411a Accessed 07 May 2020.

Tyler-Wood, T., Knezek, G., \& Christensen, R. (2010). Instruments for assessing interest in STEM content and careers. Journal of Technology and Teacher Education, 18(2), 345-368 https://eric.ed.gov/?id=EJ913648.

World Economic Forum. (2015). New vision for education unlocking the potential of technology. Resource document. World Economic Forum in collaboration with The Boston Consulting Group. http://www3.weforum.org/docs/ WEFUSA_NewVisionforEducation_Report2015.pdf Accessed 30 Oct 2020.

Yesilyaprak, B. (2011). The paradigm shift of vocational guidance and career counselling and its implications for Turkey: an evaluation from past to future. Educational Sciences: Theory and Practice, 12(1), 97-118. https://doi.org/10.14 527/9786053641742.01

\section{Publisher's Note}

Springer Nature remains neutral with regard to jurisdictional claims in published maps and institutional affiliations.

\section{Submit your manuscript to a SpringerOpen ${ }^{\circ}$ journal and benefit from:}

- Convenient online submission

- Rigorous peer review

- Open access: articles freely available online

- High visibility within the field

- Retaining the copyright to your article

Submit your next manuscript at $\boldsymbol{\nabla}$ springeropen.com 